\title{
Pelatihan Komunikasi Efektif Bagi Guru-Guru BK SMA Di Wilayah Kota Depok, Dengan Tema "Membangun Komunikasi Efektif Dengan Siswa / Remaja Kekinian"
}

\author{
Wulan Furrie \\ Program Studi Ilmu Komunikasi Institut STIAMI \\ wulanlenggana77@gmail.com
}

\section{ARTICLE INFO}

Keywords

traning

communication skills

\section{ABSTRACT}

The strength of a teacher in teaching is heavily influenced by the effective communication practiced by Dikelas-kelas. Learners are so cool with every word and story that the teacher developed. They are as stunted in the strains of beautiful melodies that splash. While this is the teaching of the teacher, the learners have the convenience of capturing it. Effective communication is very important for the learning process, because as a process where the existence of students with diverse cultures, family background and differences of viewpoints and selfstability are still vulnerable will determine The success of communication itself. The success of communication in the teaching and learning process is not only determined by the teachers but also the mental readiness condition in the teaching-learning process, as well as will be supported by environmental conditioning and Management of the school itself. There is a wide range of breakthroughs in improving communication skills for BK teachers, because BK teachers have the duties, responsibilities, and authority in the implementation of tutoring and counseling services for learners. Related to the student's selfdevelopment that suits the needs, potential, talents, interests, and personality of students at school/Madrasah.

To improve students ' learning performance, BK teachers are required to create a conducive situation and encourage students to learn more optimally both in independent learning and in class learning with enthusiasm. In order to learn to teach more communicative, there is also necessary proximity between master BK and students as an effort to establish a trust between the two.

As a manifestation and concern for the communication process that occurred in the school between the BK teachers and high school students in Depok, then the STIAMI Institute conducts effective communication training for the teachers of BK SMA. With the aim of building and improving the communication skills of master BK to support the process of teaching more effectively through communication.

The target audience of this dedication is the teachers of BK SMA in Depok. The cost of devotion is obtained from the Department of Communication in the STIAMI Institute in 2015. The event was held on 20 December 2016 at the STIAMI II campus on JL. Arif Rahman Hakim No. 3 Beji Depok, followed by 50 teachers of BK SMA. From the results of the evaluation of the results and benefits of this dedication activities include improving the communication skills of the BK SMA teachers in understanding students in the face of the learning process according to their age and "kinship". The participants were enthusiastic and actively participated in this training activity. This training is to be done on a wider target and the material can be developed on teachers other than BK teachers. Thus, it is hoped that someday help BK teachers and other teachers to develop and improve the quality of Communication to the students, so that the quality of learning is increased because it has awakened trust between teachers and students in the area of Depok. 


\section{RINGKASAN}

Kekuatan seorang guru dalam pengajaran sangat dipengaruhi oleh komunikasi efektif yang dipraktekkan dikelas-kelas. Peserta didik begitu asik dengan setiap kata dan cerita yang dikembangkan sang guru. Mereka seperti tersirap dalam alunan melodi indah yang mengasikkan. Disaat seperti ini maka pengajaran apapun yang disampaikan sang guru, peserta didik memiliki kemudahan untuk menangkapnya.

Komunikasi yang efektif sangat penting bagi proses belajar mengajar, karena sebagai proses dimana keberadaan anak didik dengan beragam budaya, latarbelakang keluarga dan perbedaan cara pandang serta kestabilan diri yang masih rentan akan menentukan keberhasilan komunikasi itu sendiri. Keberhasilan komunikasi dalam proses belajar mengajar tidak hanya ditentukan oleh pihak pengajar (guru) tetapi juga kondisi kesiapan mental anak dalam proses komunikasi belajarmengajar, disamping juga akan didukung oleh pengkondisian lingkungan dan manajemen sekolah itu sendiri.

Diperlukan berbagai terobosan dalam meningkatkan kemampuan berkomunikasi bagi guru BK, karena guru BK memiliki tugas, tanggungjawab, wewenang dalam pelaksanaan pelayanan bimbingan dan konseling terhadap peserta didik. Terkait dengan pengembangan diri peserta didik yang sesuai dengan kebutuhan, potensi, bakat, minat, dan kepribadian peserta didik di sekolah/madrasah.

Untuk meningkatkan prestasi belajar siswa maka guru BK dituntut untuk menciptakan situasi yang kondusif dan mendorong siswa dapat belajar secara lebih optimal baik di dalam belajar mandiri maupun didalam pembelajaran di kelas dengan penuh semangat. Agar proses belajar mengajar lebih komunikatif maka diperlukan pula kedekatan antara Guru BK dan siswa sebagai upaya terbangunnya sebuah kepercayaan antara keduanya.

Sebagai wujud dan kepedulian terhadap proses komunikasi yang terjadi di sekolah antara guru BK dan siswa pelajar SMA se-kota Depok, maka Institut STIAMI mengadakan pelatihan komunikasi efektif bagi bagi guru-guru BK SMA. Dengan tujuan membangun dan meningkatkan kemampuan komunikasi Guru BK guna menunjang proses belajar mengajar yang lebih efektif melalui komunikasi.

Khalayak sasaran dari pengabdian ini adalah guru-guru BK SMA wilayah kota Depok .Biaya pengabdian diperoleh dari Prodi Jurusan Komunikasi Institut STIAMI tahun 2015. Kegiatan pengabdian telah dilaksanakan pada tanggal 20 Desember 2016 yang bertempat di kampus STIAMI II di jl. Arif Rahman Hakim No.3 Beji Depok, dengan diikuti oleh 50 orang peserta guru BK SMA.

Dari hasil evaluasi diperoleh hasil dan manfaat dari kegiatan pengabdian ini diantaranya adalah meningkatkan kemampuan komunikasi guru-guru BK SMA dalam memahami peserta didik dalam menghadapi proses belajar mengajar sesuai dengan usia dan "kekinian" mereka. Peserta cukup antusias dan berpartisipasi aktif dalam kegiatan pelatihan ini. Kegatan pelatihan ini hendaknya dilakukan pada sasaran yang lebih luas dan materinya dapat dikembangkan pada guru-guru selain guru BK. Dengan demikian diharapkan kelak dapat membantu guru-guru BK dan guru lainnya dalam mengembangkan dan meningkatkan kualitas komunikasi terhadap peserta didik, sehingga mutu pembelajaran lebih meningkat karena sudah terbangun kepercayaan antara guru dan siswa di wilayah kota Depok.

\section{PENDAHULUAN}

Strategi membangun komunikasi dalam proses belajar mengajar merupakan salah satu hal yang sangat penting untuk mewujudkan proses belajar mengajar yang efektif. Karena, tanpa adanya komunikasi tidak mungkin peroses belajar mengajar akan berjalan dengan lancar, sebab komunikasi adalah kunci utama untuk berintraksi antara guru dengan peserta didik. Komunikasi bukan berarti hanya berintraksi dengan menggunakan bahasa lisan semata, akan tetapi komunikasi juga bisa dilakukan dengan menggunakan bahasa tulis dan bahasa isyarat atau gerak tubuh. Komunikasi menjadi salah satu faktor penentu keberhasilan dalam proses pembelajaran. Komunikasi yang efektif berkolerasi dengan tingkat keberhasilan pembelajaran. Untuk itu penting sekali pendidik memilih cara komunikasi dengan siswa dalam proses pembelajaran, agar kegiatan tersebut mencapai tujuan secara efektif dan efesien 
Komunikasi yang baik mampu menjadikan suasana dalam pendidikan menjadi sangat nyaman, suasana belajar yang tercipta menjadi suasana belajar yang menyenangkan, bukan malah sebaliknya menjadikan belajar itu sebagai sebuah beban. Komunikasi yag dimaksud disini adalah semua bentuk komunikasi yang terjadinya di kelas atau pada saat proses pembelajaran berlangsung, karena menurut ciri dari kurikulum 2013 bahwa belajar itu bukan hanya di kelas, namun di alam terbuka pun semua itu adalah proses belajar. Pada kenyataannya, dari zaman dahulu sampai sekarang masih banyak para guru maupun pendidik yang kurang mempunyai kemampuan untuk membangun komunikasi yang harmonis dalam proses belajar mengajar yang disebabkan oleh kurangnya kesadaran akan pentingnya komunikasi tersebut, bahkan lebih ironisnya lagi banyak guru yang tidak mampu berkomunikasi dengan efektif kepada para peserta didiknya Membangun komunikasi dengan siswa yang sudah remaja, tentu harus mengenal karakter remaja terlebih dahulu. Dengan demikian dapat memudahkan guru pada saat berkomunikasi. Mendengar pendapat serta memberi pendapat kepada siswa yang sudah remaja, Guru harus bisa memposisiskan diri sebagai teman sebaya. Artinya seorang guru harus menyesuaikan diri terlebih dulu. Guru BK memiliki jabatan sangat essensial dalam hal komunikasi dengan siswa . Guru BK dianggap guru yang paling dibutuhkan oleh siswa untuk berbagi segala permasalah yang dihadapi dalam mengikuti pelajaran dan juga biasanya guru BK orang yang bisa diajak berbicara dari hati-hati untuk mengarahkan siswa dalam memilih jenjang karir yang sesuai atau pilihan untuk melanjutkan pendidikan.

Salah satu tujuan bimbingan dan konseling sekolah adalah membantu siswa untuk mengembangkan diri, memiliki kemandirian, dan tanggung jawab dalam mengambil pilihan dan keputusan, sehingga siswa dapat menghadapi masa depan secara terarah. Siswa diharapkan memiliki kepribadian yang efektif, kreatif, dan produktif, serta mampu berinteraksi, menyesuaikan diri, dan mengembangkan lingkungan kehidupan sebagai fasilitas perkembangan yang kondusif. Layanan bimbingan dan konseling berupaya membantu siswa agar mereka dapat menjalani proses belajar secara efektif dan mandiri.Siswa diharapkan memiliki ketangguhan dan kemampuan dalam menghadapi berbagai peluang, mengatasi kendala kehidupan,dan responsif dalam menghadapi kesempatan yang muncul untuk mengaktualisasikan potensi-potensi yang mereka miliki. Sebagai pelaksanaan bimbingan dan konseling di sekolah, Guru BK perlu memperhatikan adanya kompleksitas kehidupan masyarakat serta berbagai persoalan yang ditimbulkannya, yang berimbas pada remaja. Peran Guru BK sangat diperlukan untuk membangun komunikasi yang efektif bagi siswa disekolah. Untuk itu diadakanlah pelatihan ini untuk melatih dan membekali keterampilan komunikasi bagi guru-guru BK di kota Depok. sehingga dapat melatih, mengasah dan meningkatkan kemampuan komunikasi dan menyampaikan informasi atau pesan yang jelas dan dapat dipahami dengan mudah oleh siswa.

\section{Tinjauan Pustaka}

\section{Guru Bimbingan Konseling (Guru BK)}

Peran guru bimbingan dan konseling sangat diperlukan sehingga kegiatan belajar dapat berlangsung dengan baik sesuai dengan apa yang diharapkan. Bimbingan dan konseling merupakan pelayanan dari, untuk, dan oleh manusia memiliki pengertian yang khas. Dengan bimbingan dan konseling tersebut, siswa akan melakukan aktifitas belajar sesuai dengan apa yang telah ditentukan, atau telah diatur dalam suatu aturan (norma). Sebagaimana dikemukakan oleh Moeliono (1993: 208) bahwa disiplin adalah ketaatan (kepatuhan) kepada peraturan tata tertib, aturan, atau norma.

Kehadiran guru bimbingan dan konseling (guru BK) di Indonesia masih relatif baru. Pada awal 1970-an, profesi ini baru diperkenalkan di negeri ini. Di negeri Paman Sam tempat dilahirkannya profesi ini; guru BK dikenal dengan istilah scholl counselor (konselor sekolah). Di Indonesia, pada awalnya dikenal dengan sebutan guru BP (bimbingan penyuluhan). Karena dalam konteks tugas istilah "konseling" lebih sesuai daripada "penyuluhan", pada tahap selanjutnya sebutan guru BP berubah menjadi guru BK (bimbingan konseling). Pada beberapa daerah ada pula guru BP yang disebut dengan istilah guru pembimbing. Akhir-akhir ini, penggunaan sebutan "konselor" lebih dianjurkan.Dalam UU Nomor 20 tahun 2003 Pasal 1 Ayat (6) disebut istilah "konselor" untuk profesi pendidik ini. Lebih lanjut dalam buku Rambu-Rambu Penyelenggaraan Bimbingan dan Konseling dalam Jalur Pendidikan Formal yang dikeluarkan Dirjen PMPTK Depdiknas tahun 2007, dijelaskan pendidikan minimal konselor adalah sarjana (S1) program studi bimbingan dan 
konseling. Diharapkan setelah lulus pendidikan akademik dan memperoleh gelar sarjana pendidikan (S.Pd) jurusan bimbingan dan konseling, lulusan dapat melanjutkan pendidikan profesi konselor (PPK).

Dasar pemikiran penyelenggaraan bimbingan dan konseling di Sekolah/Madrasah, bukan semata-mata terletak pada ada atau tidak adanya landasan hukum (perundang-undangan) atau ketentuan dari atas, namun yang lebih penting adalah menyangkut upaya memfasilitasi peserta didik yang selanjutnya disebut konseli, agar mampu mengembangkan potensi dirinya atau mencapai tugas-tugas perkembangannya (menyangkut aspek fisik, emosi, intelektual, sosial, dan moral-spiritual).

\section{Komunikasi Efektif}

Komunikasi efektif yaitu kemampuan menjadi pendengar yang baik, sehinggakomunikator dapat memahami, bertanya dan menjawab dengan tepat. Apabila seseorang tidak memiliki kemampuan mendengar yang baik maka hambatan komunikasi akan sangat mudah terjadi dan kesalahpahaman akan sangat mudah timbul.

Dengan kemampuan berkomunikasi efektif yang baik dan elegan, pesan yang ingin disampaikan dapat diterima dengan baik juga oleh teman bicara, sehingga respon yang didapat pun terhindar dari kesalahpahaman dan salah pengertian. Komunikasi efektif merupakan hal yang sangat penting dalam berinteraksi dengan orang lain, dan setiap mahluk pasti selalu melakukan komunikasi dengan caranya sendiri, karena itulah keterampilan komunikasi efektif mutlak harus dimiliki oleh siapapun, baik dalam lingkup keluarga, organisasi, dan juga pekerjaan.kebutuhan seseorang untuk dapat berinteraksi dengan orang lain atau kelompok.

Stephen Covey menekankan konsep kesalingtergantungan (interdependency) untuk menjelaskan hubungan antarmanusia. Unsur yang paling penting dalam komunikasi bukan sekadar pada apa yang kita tulis atau kita katakan, tetapi lebih pada karakter kita dan bagaimana kita menyampaikan pesankepada penerima pesan. Jika kata-kata atau pun tulisan kita dibangun dari teknik hubungan manusia yang dangkal (etika kepribadian), bukan dari diri kita yang paling dalam (etika karakter), maka orang lain akan melihat atau membaca sikap kita. Jadi syarat utama dalam berkomunikasi efektif adalah karakter yang kokoh yang dibangun dari pondasi integritas pribadi yang kuat.

Menurut Stephen Covey, justru komunikasi merupakan ketrampilan yang paling penting dalam hidup kita. Kita menghabiskan sebagian besar jam di saat kita sadar dan bangun untuk berkomunikasi. Sama halnya dengan pernafasan, komunikasi kita anggap sebagai hal yang otomatis terjadi begitu saja,sehingga kita tidak memiliki kesadaran untuk melakukannya dengan efektif. Kita tidak pernah dengan secara khusus mempelajari bagaimana menulisdengan efektif, bagaimana membaca dengan cepat dan efektif, bagaimana berbicara secara efektif, Syarat utama untuk agar komunikasi menjadi efektif adalah kredibilitas ketrampilan komunikasi antar perorangan adalah kemampuan untuk terus menerus membangun kredibilitas dan dapat dipercayanya segaa apa yang kita komunikasikan. Untuk membangun kredibilitas harus ada isi pesan yang jelas, Sura / intonasi dalam menyampaikan pesan dan cara bagaimana orang itu menyampaikan pesan.

\section{Remaja Kekinian}

Kalimat 'remaja kekinian' saat ini sedang menjadi tren. Remaja kekinian berarti remaja yang mengikuti perubahan jaman, baik dari segi fashion, teknologi, sikap, perilaku dan kebiasaan sehariharinya. Remaja kekinian itu mereka yang berusia 12-18 tahun.Remaja kekinian senang bereksperimen, bereksplorasi, memiliki banyak fantasi dan khayalan, mengikuti perubahan jaman, mulai dari fashion, bahasa, sampai teknologi untuk memperoleh pengakuan dari orang-orang di sekitarnya dengan cara update status atau upload foto maupun video di sosial media.

Remaja ini selalu ingin menonjolkan eksistensi dan identitasnya pada orang lain. Remaja aka sangat tertekan bila mereka tidak ada yang mengakui, alhasil mereka selalu ingin diperhatikan jika tidak mereka akan mencari perhatian, apapun caranya, apapun resikonya. Mudah saja untuk mengukur seberapa kekiniannya remaja sekarang. Kita bisa melihat dari penampilannya, baju baju branded distro, jam tangan hidup atau mati, hingga aksesoris lainnya.Kemudian gaya hidup, remaja ini akan terlihat dengan siapa mereka bergaul, dengan cara bagaimana mereka bergaul, apa 
yang mereka lakukan, hingga makanan apa yang mereka santap. Terakhir adalah tempat mereka terbiasa me nongkrong, mulai dari yang anehhingga ada ada saja. Para remaja biasanya berdebat terlebih dahulu tentang dimana mereka akan singgah, mengeluarkan banyak argumen dan pertimbangan. Akhirnya karena terlalu lama, mereka malah saling terserah alias saling nunjuk setuju dengan rekomendasi tempat temannya, padahal ketika sudah sampai, ngedumel karena tidak nyaman dengan suasananya.

Di lokasi tempat mereka biasa mengobrol, ( biasa disebut tempat nongkrong) ada ritual yang sering remaja lakukan, yakni selfie bareng atau wefie/groufie. Biasanya menggunakan kamera handphone, atau yang niat menggunakan kamera DSLR yang settingannya tidak pernah berubah, alias mode auto paten. Kemudian mereka memesan makan atau minum, tapi sebagian besar dari mereka hanya memesan minum saja, dengan dalih berhemat, hanya tetap saja harga minuman di tempat nongkrong kekinian selalu lebih mahal. Anehnya mereka bisa bertahan lama di tempat nongkrong, padahal hanya memesan satu minuman. Hal yang membuat mereka bertahan adalah wifi yang tersambung ke smartphone/laptop mereka, Tidak perduli wifi lambat (biasa disebut lemot) tetap membuat mereka bertahan , dan berharap orang - orang di sana untuk memnutuskan sambungannya ke wifi, supaya wifi yang dia gunakan tidak lemot.Remaja seperti itu rela hanya makan sekali sehari denga lauk yang seadanya dan minim gizi demi nongkrong kekinian di tempat kekinian.

\section{Tujuan, Manfaat Dan Kerangka Pemecahan Masalah \\ 1. Tujuan Kegiatan}

Tujuan kegiatan pengabdian kepada masyarakat ini, yang dilakasanakan melalui kegiatan pelatihan Komunikasi Efektif bagi guru-guru BK di wilayah kota Depok, dengan tema " Membangun Komunikasi Efektif dengan Siswa / Remaja Kekinian" adalah :

1. Memberi bekal pengetahuan dan ketrampilan pada guru-guru BK tingkat SMA sekota Depok dalam berkomunikasi secara efektif kepada siswa/ peserta didik.

2. Membekali peserta pelatihan dalam menghadapi siswa yan memilii masalah secara spesifik

3. Melatih guru-guru BK sekota Depok untuk berkomunikasi secara efektif dengan siswa / peserta didik disekolah masing-masing

\section{Manfaat kegiatan}

Kegiatan pengabdian ini memiliki beberapa manfaat baik langsung maupun tidak langsung bagi guru-guru BK SMA diantaranya dapat meningkatkan keterampilan dan kreatifitas guru dalam berkomunikasi dengan siswa, meningkatkan rasa percaya diri guru BK dalam menghadapi siswa, Melatih cara berkomunikasi yang efektif dengan Siswa.

\section{Kerangka Pemecahan masalah}

Alternatif pemecahan masalah dilakukan dengan mengadakan pelatihan komunikasi efektif khususnya untuk menghadapi Siswa / peserta didik di SMA di sekolah masing-masing (Se kota Depok) dimana diharapkan guru-guru BK SMA memilki pengetahuan dan keterampilan dalam berkomunikasi secara efektif dengan siswa .

\section{Pelaksanaan Kegiatan}

\section{A. Realisasi Pemecahan masalah}

\section{a. Persiapan Kegiatan pengabdian pada masyarakat}

Sebelum kegiatan dilaksanakan maka dilakukan persiapan-persiapan sebagai berikut:

1. Melakukan studi pustaka tentang berbagai media pembelajaran komunikasi efektif

2. Melakukan persiapan alat dan bahan untuk melatih peserta

3. Menentukan waktu pelaksanaan dan lamanya kegiatan pengabdian bersama-sama tim pelaksana

4. Menentukan dan mempersiapkan materi yang akan disampaikan dalam kegitan pengabdian masyarakat.

\section{b. Pelaksanaan kegiatan pengabdian}


Pelaksanaan kegiatan pengabdian berlangsung pada hari Sabtu, 20 Desember 2016 dari jam 0.800 WIB s.d $16.00 \mathrm{WIB}$, dengan dihadiri 50 orang peserta, guru-guru BK SMA se kota Depok. Kegitan berupa penyampaian materi dan praktek langsung cara berkomunikasi efektif kepada untuk siswa/peserta didik.Dibagi menjadi 10 kelompok Setiap kelompok melakukan praktek langsung setelah diberikan penjelasan oleh tim instruktur.

\section{c. Khalayak Sasaran}

Khalayak sasaran yang dipilih adalah guru-guru BK SMA sekota Depok Tempat yang dipilih adalah Institut STIAMI kampus ARH Depok. JL. Arif Rahman Hakim no.3 Beji-Depok.

\section{d. Relevansi bagi Guru}

Kegitan pengabdian ini memiliki relevansi dengan kebutuhan peningkatan ketrampilan komunikasi untuk siswa. Berdasarakan hasil survey sebelum pelaksanaan, guru-guru BK SMA masih/ kadang mengalami kesulitan dalam berkomunikasi dengan peserta didik disekolah masingmasing, terutama pada siswa yang memiliki masalah spesifik karena keterbatasan pengetahuan dan ketrampilan komunikasi.. Sehingga dengan adanya pelatihan ini diharapkan guru dapat memiliki ekal dan lebih percaya diri dalam berkomunikasi dengan siswa.

\section{B. Hasil Kegiatan}

\section{Hasil Lokakarya dan pelatihan}

Berdasarkan wawancara, tanya jawab dan pengamatan langsung selama kegiatan berlangsung, kegiatan pengabdian pada masyarakat ini memberikan hasil sebagai berikut:

1. meningkatnya pengetahuan dan pemahaman serta ketrampilan guru BK SMA dalam

2. merancang dan membangun komunikasi yang efektif kepada siswa

3. meningkatnya keterampilan guru BK SMA dalam meningkatkan rasa percaya diri bagi peserta didik

\section{Faktor pendukung dan faktor penghambat}

Beberapa faktor yang mendukung terlaksananya kegiatan pengabdian pada masyarakat ini adalah besarnya minat dan antusiasme peserta selama kegiatan, sehingga kegiatan berlangsung dengan lancar dan efektif. Sedangkan faktor penghambatnya adalah keterbatasan waktu pelatihan serta masih kurangnya ketersediaan alat-alat pendukung

\section{KESIMPULAN DAN SARAN}

\section{a. Kesimpulan}

Dari kegiatan pengabdian pada masyarakat ini dapat disimpulkan bahwa:

1. Pengetahuan dan pemahaman guru BK SMA dalam melakukan komunikasi efektif lebih meningkat

2. Keterampilan guru-guru BK SMA dalam meningkatkan rasa percaya diri juga meningkat

b. saran

Mengingat besarnya manfaat kegiatan pengabdian pada masyarakat ini, maka selanjutnya perlu:

1. Mengadakan pelatihan serupa dan tidak terbatas hanya untuk guru-guru BK SMA

2. Adanya kesinambungan dan monitoring program pasca kegiatan pengabdian ini sehingga guruguru BK SMA benar-benar dapat mempraktekan ketrampilan yang sudah dimiliki

\section{DAFTAR PUSTAKA}

H. Syamsu Yusuf LN. Rosda Badung. 2002. Psikologi perkembangan anak dan remaja

Hilmawati, Fenti. (...). Bimbingan Konseling. PT Raja GrafindoPersada.Yakarta

N.Ardi Setyano, Diva Press. 2015. Interaksi dan komunikasi efektif. : belajar mengajar guru untuk sehari-hari 